\title{
Chera, Chola, Pandya: Using Archaeological Evidence to Identify the Tamil Kingdoms of Early Historic South India
}

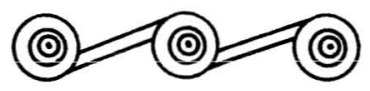

\author{
SHINU A. ABRAHAM
}

DESPITE THE AMOUNT OF ARCHAEOLOGICAL RESEARCH that has been carried out in South India, our understanding of the South Indian protohistoric period is still, in many ways, in its infancy. It is only recently that scholars have begun to move away from traditional culture-historical approaches and to draw on the archaeological data to answer specific questions about the processes and conditions surrounding emerging social complexity. Like many other regions of the world that possess a literary tradition, South Asia's past has been largely built on a foundation of epigraphic and textual evidence (e.g., Kulke and Rothermund 1986; Sastri 1966); one could argue that, for the time period spanning the transition from prehistory to history, it has been South Asia's documentary record that has chiefly determined current interpretations of its early history. In the same way, the onset of written records in South India made it possible to move away from the tendency to treat the entire peninsular region as a whole and to isolate smaller regions whose texts indicated distinct historical trajectories. In the southern portion of the peninsula - the region that corresponds roughly to the presentday states of Kerala and Tamil Nadu - the existence of a large documentary corpus, both indigenous and foreign, and the occurrence of inscribed coins and cave inscriptions, have given rise to the idea of a separate ethnic and linguistic region known as "Tamilakam" (Fig. 1).

By contrast, the role of archaeology in the consideration of early Tamil identity has been more or less secondary. The common tendency is for South Indian historians to appropriate the archaeological data as a source of correlates for information gleaned from the texts (e.g., Champakalakshmi 1996; Gurukkal 1989; Thapar 1992) - in other words, to use the material record to search out "known" historical patterns, events, or places (Morrison and Lycett 1997:216). Archaeologists are equally culpable; it has become customary for South Indian archaeologists to label sites and objects in Kerala and Tamil Nadu as "Tamil," without considering whether signifiers exist in the material record that substantiate or

Shinu A. Abraham is visiting assistant professor in the Department of Anthropology, St. Lawrence University, Canton, New York.

Asian Perspectives, Vol. 42, No. 2 (c) 2003 by University of Hawaic $i$ Press. 


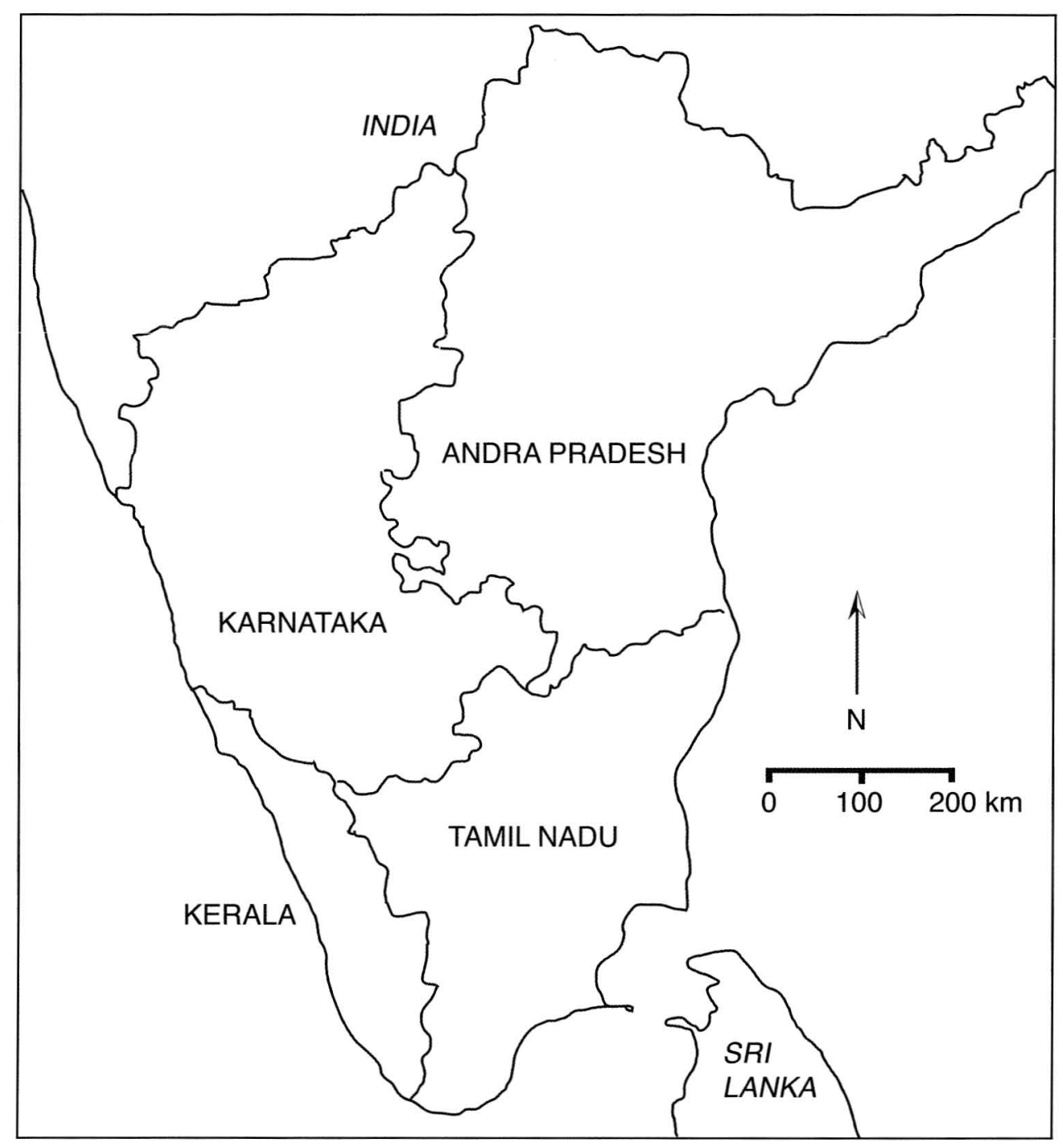

Fig. 1. States of South India.

refute this notion of cultural separateness. The underlying assumption continues to be that the documentary record serves as the best and most reliable source for knowledge about past identity. As will be demonstrated here, the archaeological data from protohistoric Kerala and Tamil Nadu is not so clear-cut and, in fact, appears to challenge the very notion of a separate culture region. By carefully separating and analyzing the written and material records for Tamilakam (Fig. 2), this study will examine what, if anything, it meant to have a Tamil identity in Early Historic South India.

\section{ARCHAEOLOGY, HISTORY, AND IDENTITY}

The relationship between archaeology and history has become a mounting concern among archaeologists, and research in other regions highlights some of the 


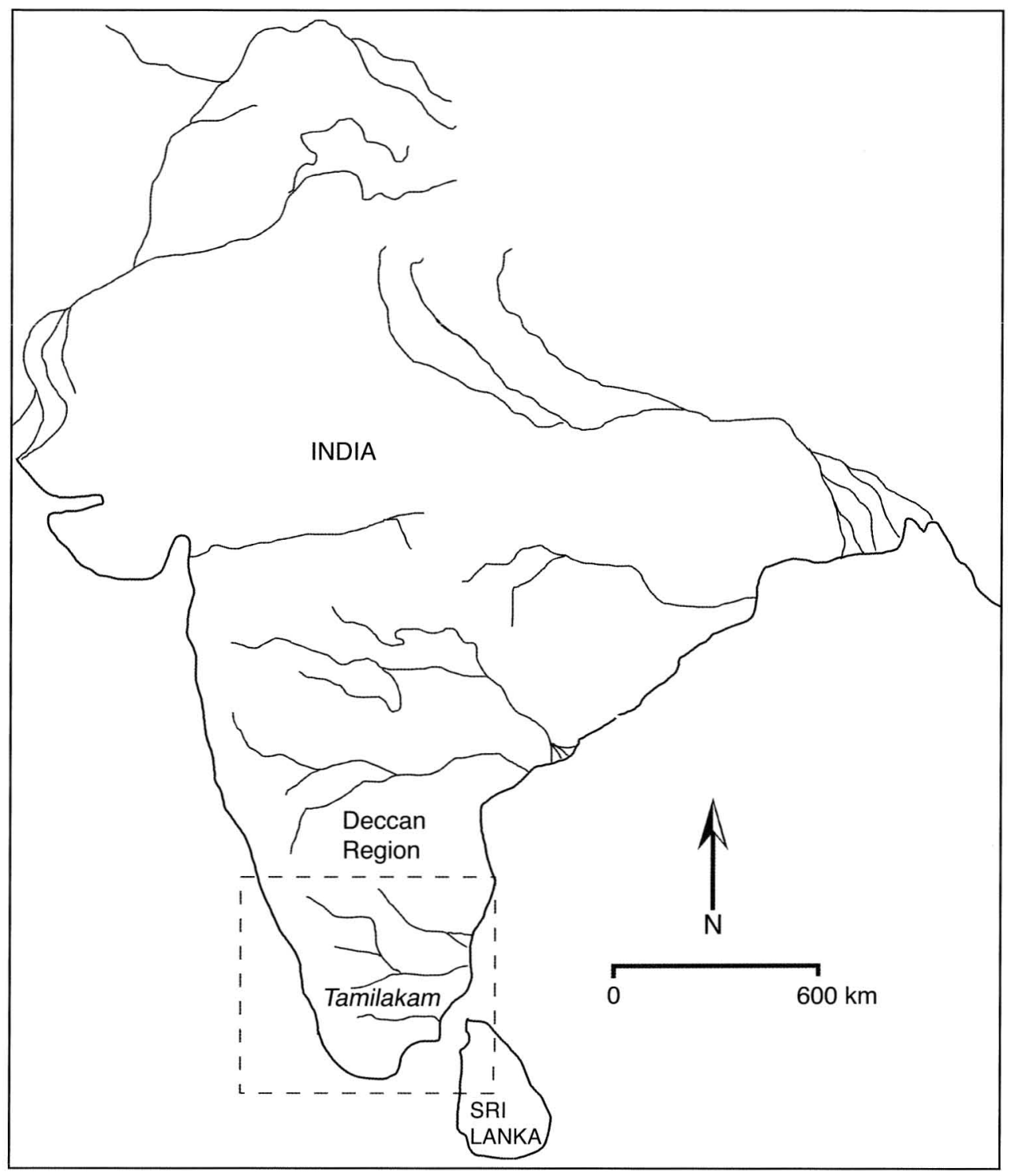

Fig. 2. Location of Tamilakam (c. 300 B.C.-A.D. 300).

issues that are relevant to this study of Kerala and Tamil Nadu. Many archaeologists agree, for instance, that the overwhelming tendency is to privilege the information contained in texts at the expense of data derived from the archaeological record (e.g., Feinman 1997; Morrison and Lycett 1997). Conflicts also emerge when historians focus on the texts at the expense of other materials, while archaeologists limit their efforts to single-site evaluations (Thurston 1997:260). Also, archaeologists themselves can be prejudiced in their selective use of written records to support their findings (Feinman 1997:372). Nevertheless, the rationale for conducting historically informed archaeology is indisputable; combining the 
historical and archaeological data sets must lead to richer perspectives on the complexities of the past.

Recognizing that history and archaeology are both media by which the past can be accessed, the most basic way of linking the two is to use one record as a means of identifying or corroborating information recovered by the other. Leone and Potter (1988) argue that Binford's middle-range theory may be adapted from ethnoarchaeological studies to the documentary record-in other words, that textual evidence should be used to set up "descriptive grids" (Leone and Potter 1988:13), based on the documentary record, against which the archaeological data can be analyzed. Essentially, the documents would provide testable questions that the material remains may be able to answer, and the answers in turn will offer insights into both the documentary and material records and their relationship (Leone and Crosby 1987:14). Kosso likens the relationship between texts and artifacts to the use of testimony and physical evidence in a court trial (Kosso 1995:182): each line of evidence can be used potentially to evaluate the other. Although the two sources are seldom about the same event, peoples, or objects, they are often about related things (Kosso 1995:183), and hence may be used in conjunction with one another to recreate the past. Kosso is careful to acknowledge the lack of complete independence between historical and archaeological forms of evidence but proposed that, with a systematic enumeration of the distinctions, it may be possible to compare and contrast the claims of each line of evidence. Wylie (1985) espouses a similar approach in her discussion about the use of analogy in archaeology. One kind of link often established between archaeological and textual records (particularly in South Indian archaeology) is the one rooted in analogical reasoning, i.e., the use of knowledge from one record to make inferences about the second record, based often on assumptions of uniformitarian principles. Although Wylie is referring to archaeological and ethnographic sources in her essay, the same debates apply to archaeological and historical sources.

The interplay of material data and historical texts especially resonates during the quest for past social identities. In the case of people who have left documentary records, the historical references to specific past groups lead inevitably to the labeling of sites and objects (Jones 1997:27). At first glance, trying to locate cultural or ethnic identity may look suspiciously like an outdated attempt to superimpose old culture-historical taxonomies on early South India. The definition of ethnicity itself is beset by difficulties. Shennan (1989:14) states, "ethnicity must be distinguished from mere spatial variation and should refer to self-conscious identification with a particular social group at least partly based on a specific locality or origin." One cannot simply search for artifact patterning in order to locate ethnicity, any more than one can locate archaeological "cultures," since this variation arises from the result of an enormous range of different processes. Conversely, a particular material form may remain the same, but its meaning will alter in different contexts; it will be used in different ways according to different historical traditions and social contexts (Shanks and Tilley 1987).

It is commonly assumed that studies of ethnicity require access to people's self-conscious reflections on identity (Jones 1999:220), and that written sources provide the most reliable accounts of such reflections. Once such issues are understood through an analysis of texts, the archaeologist may try to search for material markers of ethnicity in the archaeological record. But the archaeolog- 
ical pursuit of groups named in historical texts gives rise to a new set of issues. Names recorded in texts are often deliberate records of information about rulers and bureaucrats, rather than the self-identifications of the general population (Emberling 1997:313). The boundaries defined in the texts may not match boundaries found in the material record, and the texts may also obscure ongoing processes of identity formation and re-formation. The situation is compounded by the fact that the material record of complex societies may have been manipulated in their turn and may in fact obscure actual relations of power (Morrison and Lycett 1994:327). The texts do not provide, "self-evident meaning and cannot, in themselves, solve archaeology's central methodological challenges" (Morrison and Lycett $1997: 233$ ).

Despite the theoretical concerns and methodological constraints, the influence of text-based knowledge on the evaluation of archaeological data is undeniable and even inevitable, at least in the case of South India. It is not possible at this stage to confidently propose a solution, but perhaps by considering the early Tamil written and material records separately, one may begin to understand the informational gap between the two data sets and suggest possible ways to narrow that gap.

\section{“TAMILAKAM” AS A HISTORICAL ENTITY}

The evidence for the identification of Tamilakam as a distinct culture region is culled from a variety of text-based sources. The most important of these is a body of prose poetry referred to as the "Sangam Anthology" - indigenous texts dating to the first few centuries A.D. that comprise the earliest extant examples of Tamil literature. The works that have survived include eight anthologies and ten idylls, a work on grammar, and 18 minor works. There are altogether 2381 poems by 473 poets and 102 poems by anonymous authors, besides the grammar and 18 minor works (Hart 1975:7). Scholars are divided about the chronology of these works, and propose dates ranging from the first century B.C. up to the sixth century A.D. (Hart 1975; Ray 1995; Zvelebil 1992). Appreciating the Sangam corpus as a source of historical data requires understanding their poetic and bardic nature: a bulk of the poetry is concerned with extolling the exploits of rulers, warriors, and patrons (Champakalakshmi 1996:175) — a fact that has not prevented historians and archaeologists alike from using the information contained in the texts as referents for the archaeological record. The texts describe the, "cool land of the Tamils" (Hart and Heifetz 1999:28) and many lines are taken up with glorifying the military exploits and bravery of the leaders of the three principal Tamil polities, the Chera, Chola, and Pandya. The term occurs often enough in the Sangam literature, such that to speak of "Tamilakam," a "Tamil" land, and a "Tamil" people, implies some sense of cultural or ethnic identity-or at least some consciousness of independence or separateness from neighbors to the north and south.

Also important in the identification of Tamilakam is inscriptional evidence. Within Tamil Nadu, for example, about 80 to 90 rock inscriptions have been discovered in natural caverns. Along with fragmentary epigraphs on potsherds from around 25 sites in southern India (Zvelebil 1992:123) and outside South Asia (Mahadevan 1993), they form the strongest linguistic evidence for separating Tamilakam from the rest of South India. The inscriptions range from third 
or second century B.C. to second or third century A.D., and are written in the Brāhmī script, which was common throughout the peninsula at the time, but the language is an early form of Tamil. The Tamil inscriptional data varies from the Sangam texts, since they have a different source and were recorded for different purposes. These inscriptions were written in what are believed to be Buddhist or Jain ascetic caves, and their purpose seems to be to remind travelers of the bounty of various merchants and kings and their support for these sects (Kennedy 1976:6). The inscriptions mostly contain personal and occupational names of donors who endowed the Buddhist and Jain monks with stone beds in caverns (Gurukkal 1989:160), and one of their greatest benefits is that they confirm certain king and place names that are mentioned in the earliest Sangam texts (Zvelebil 1992:124).

Non-Tamil South Asian inscriptions also include references to Tamilakam. Among the most pivotal are the rock edicts of the North Indian Mauryan emperor Aśoka, dated to third century B.C. One of the edicts refers to five independent states that presumably existed beyond the southern border of his empire: the Choda (Chola), Pandya, Satiyaputra, Keralaputras (Chera), and Tamraparni (Sri Lanka) (Zvelebil 1992:110) —an indication that the polities of Kerala, Tamil Nadu, and Sri Lanka were not incorporated into the Mauryan realm (Fig. 3). Also relevant is the central Indian Hathigumpha inscription (possibly from the second half of the second century B.C.), which discusses the destruction of a "confederacy of Tamil powers" (Zvelebil 1992:103).

Outside of South Asia, it is the Greco-Roman writings that provide the most detailed historical information about Tamilakam. India is in fact frequently mentioned in the Western classical literature (McCrindle 1971 : xxi). The protohistoric period in South India coincides with a phase of South Asian participation in the flourishing maritime networks of the Indian Ocean. The South Asian subcontinent is well known for having had long-standing, varied, and complex forms of interaction with the external world, and South India is no exception. Historical and archaeological reconstructions of South India during its Early Historic period have placed a great deal of emphasis on the long-distance maritime trade networks to which South India belonged-particularly its links with the Roman Empire (Begley 1996; Ray 1989, 1994, 1995). The network incorporated a number of regions along the Indian Ocean littoral-including the Red Sea coast (Saloman 1991; Sidebotham 1986), the Arabian coast (Whitehouse and Williamson 1973), East Africa (Munro-Hay 1996), Southeast Asia (Ray 1994; Smith 1999), Sri Lanka (Munro-Hay 1996), and China (Ray 1994) — and South India acted as a major node in the interregional transmittal of goods during Hellenistic and Roman times (Charlesworth 1926). Of all the historical sources available for Tamilakam, the Greco-Roman references to South India are particularly useful since they are to a large degree datable and help, therefore, to fix the centuries during which overseas trade flourished. However, most of these texts refer not to "Tamilakam," but to specific trade centers and ports in peninsular India.

THE ARCHAEOLOGY OF PROTOHISTORIC KERALA AND TAMIL NADU

Although extensive portions of Kerala and Tamil Nadu have been explored and a number of sites excavated (general overviews of the region's archaeology can be found in Brubaker 2001; Gurukkal and Varrier 1999; Gurumurthy 1991; Leshnik 


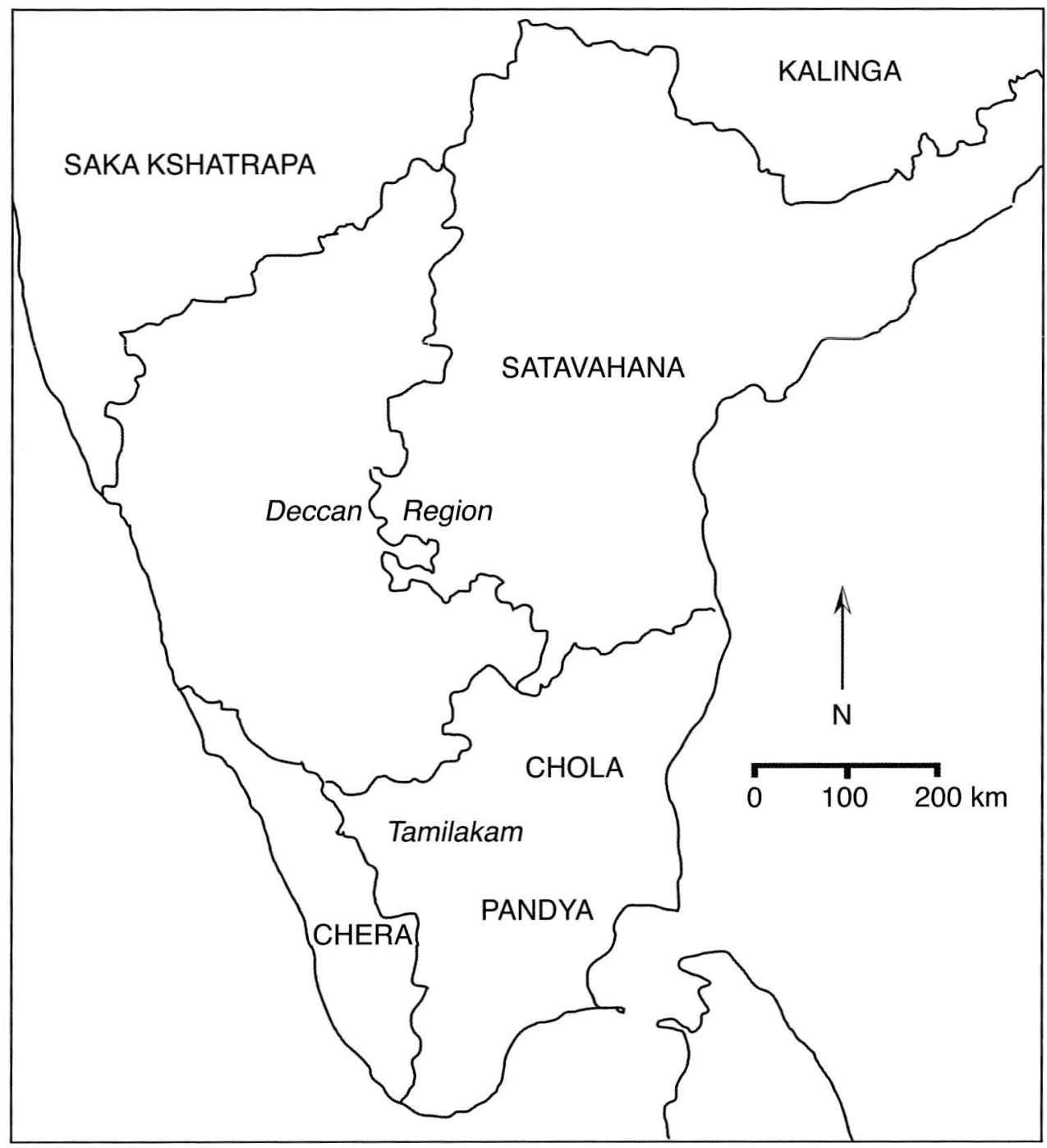

Fig. 3. Polities in early South India (c. 200 B.C.-A.D. 300).

1974; Moorti 1994; and Ramachandran 1980), the archaeological record for Tamilakam is far from satisfactory. Relatively few radiocarbon dates are available, and there are, unfortunately, no clear sequences or patterns in artifact assemblages that have permitted the development of internal relative dating sequences. Documentation of sites has been inconsistent at best-most published data on Iron Age burials take the form of brief notices, for example, and when excavations reports are available, they tend to rely on existing ill-defined artifact classification schemes. Another issue is the fragmentary nature of archaeological research in South India. Most synthetic studies are delimited by state, making it difficult to understand ancient regional patterns that crossed modern political boundaries. Also, scholars have tended to compartmentalize areas of research, focusing on certain site types, such as Iron Age burials or Early Historic settlements, or on 
specific material assemblages, such as cave inscriptions or coins. Although some South Indian historians have understood the need to treat all these elements as interrelated parts of a single past social formation (see, for example, Gurukkal $1995: 239-240$ ), it is only recently that archaeologists are coming to the same realization.

A general overview of the archaeological record of Tamilakam will be presented here in order to evaluate the extent to which issues of identity can be addressed. Archaeologically, the Tamil Sangam era corresponds roughly to the late Iron Age-Early Historic period (c. 300 B.C. to A.D. 300), which represents a key stage in the development of South Indian material culture. In addition to Iron Age burial/commemorative monuments (Fig. 4), ceramic types, and metal

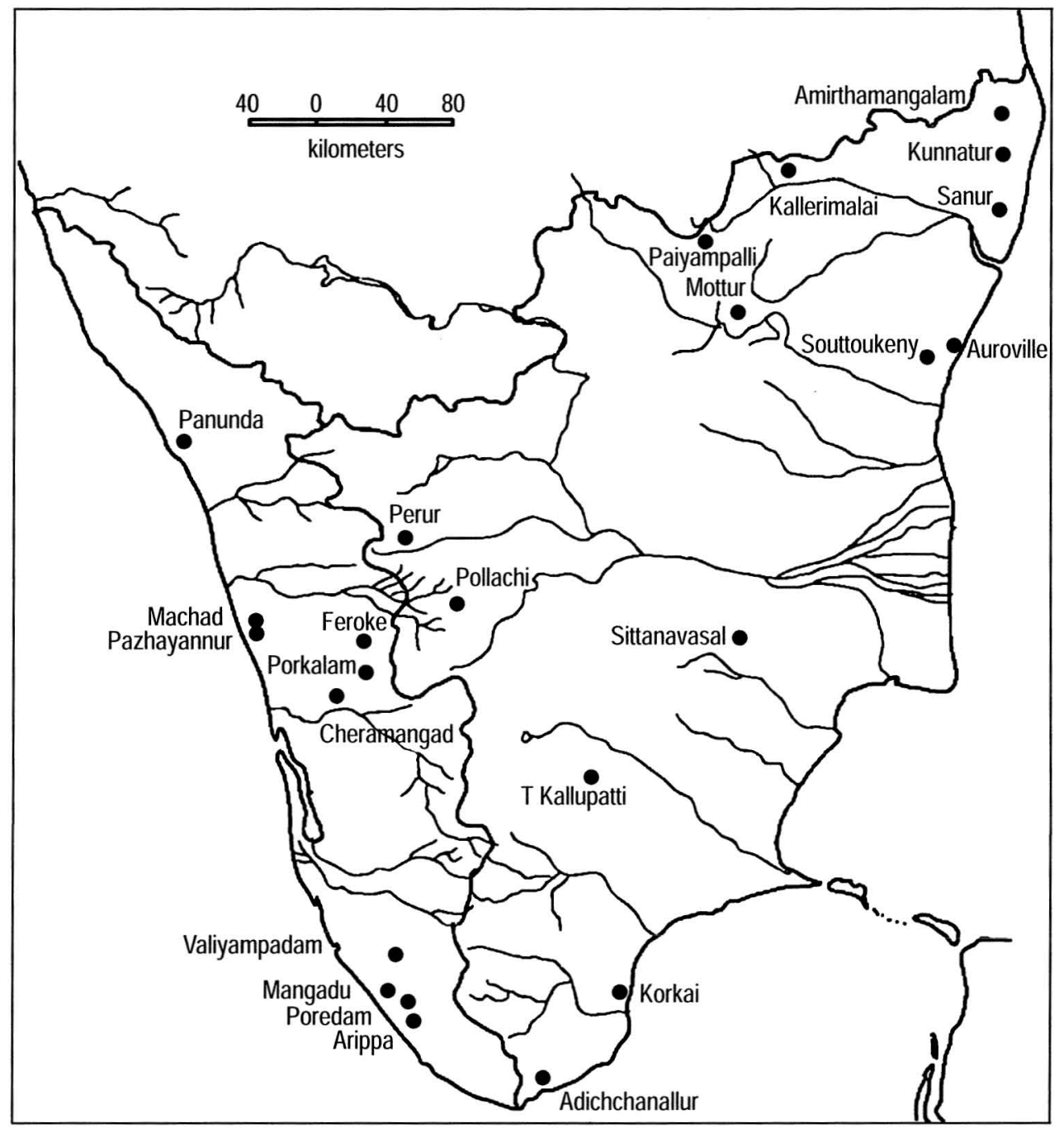

Fig. 4. Excavated Iron Age burials in Tamilakam. 
and stone artifacts, the onset of the Early Historic phase witnessed the appearance of coastal and inland settlements, new ceramic categories, numismatic and inscriptional finds, and evidence for a burgeoning overseas trade.

Excavated sites in Kerala and Tamil Nadu can be broadly categorized as burials or settlement sites (Fig. 5), or a combination of the two. The South Indian Iron Age is associated most closely with the hundreds of burial/commemorative structures that span the peninsula. Popularly and collectively referred to as "megaliths," the distribution of these features is vast and covers numerous culture regions in South Asia, including Sri Lanka. Of the locally made ceramics traditionally associated with the South Indian Iron Age, a type referred to as Black-and-Red Ware is the earliest and most well known, and one of the most widely distributed chronologically and geographically. It is found in Iron Age settlements, Iron Age

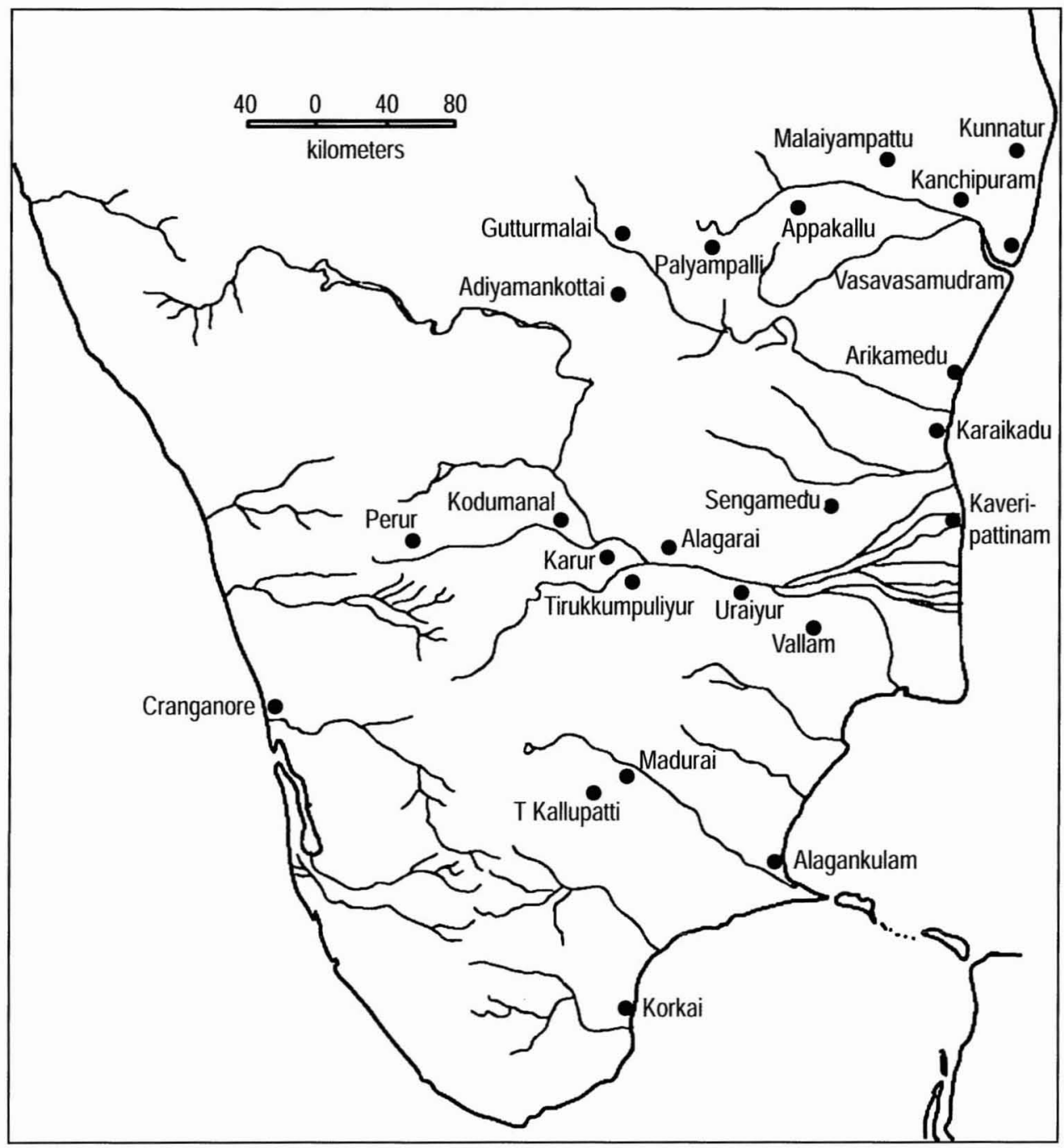

Fig. 5. Excavated settlements in Tamilakam. 
burials, and Early Historic sites in South India. Megaliths and craft objects allied with them-Black-and-Red Ware, beads, bangles, terracotta forms, metal implements, etc.- appear throughout the peninsula, extending northward as well as south into Sri Lanka, and they have been treated, by archaeologists and historians alike, largely as a singular phenomenon. The general uniformity in architectural elements and material culture has led most scholars to believe that the megaliths belonged to the same cultural complex-a long-standing yet untenable conclusion, given the relatively few monuments that have been excavated systematically and the paucity of radiocarbon dates (Moorti 1994:4). Moreover, very few studies specifically examine variability within and among megalith complexes (e.g., Leshnik 1974; McIntosh 1985; Moorti 1994), and they disagree on the extent of identifiable social differentiation.

The Early Historic phase in Tamilakam coincides with a number of new material developments in Peninsular India. One of the most important is the beginning of writing in the form of inscriptions on pottery and on cavern walls. Another important change is the introduction of a range of artifacts of foreignmostly Mediterranean-manufacture. Roman coins, amphorae, and ceramics are commonly associated with the Early Historic occupation at Tamil sites and accepted as tangible evidence of the overseas trade in which South India engaged at the time. The Early Historic period is also associated with the beginning of urban living in Tamilakam (the sites assigned to this period are exclusively settlements), as evidenced by the number of sites, both coastal and inland, containing architectural features that include brick structures, ring wells, pits with drains, and possible industrial items like soakage jars, dyeing vats, and terracotta ovens (e.g., Begley 1996; Mahalingam 1970; Nagaswamy 1995; Rajan 1994; Raman 1988; Soundara Rajan 1994). The same craft industries associated with the late Iron Age phase continue into the Early Historic phase and were perhaps supplemented by other activities such as gold working and weaving. And, along with foreign coins, the occurrence of local coins indicates at least the beginnings of a monetary system of exchange.

The locally produced artifacts associated with early Tamil sites include a few pottery types, the most important of which, in addition to the aforementioned Black-and-Red Ware, include Rouletted Ware and Russet-Coated Painted Ware. Again, issues such as variation and dating of these ceramic types are critical to the understanding of Tamil social organization, but aside from Gogte's (1997) argument for a Bengal-based origin for Rouletted Ware, few studies question the apparent geographical and temporal uniformity of these ceramics in South India. Local coins are occasionally found in or near Early Historic sites. Iron is pervasive, in the form of agricultural tools and hunting and war implements; other typical artifacts include copper and bronze objects, beads, terracotta figurines, and shell and glass bangles.

The link between social boundaries and material culture is undeniably complex, and the very concept of social boundaries and its anthropological and archaeological application is still being debated within the scholarly community (e.g., Hegmon 1998). Whatever the specific medium of material culture and the particular past that is being studied, a major goal in the study of formal variation across space is, "to identify social groups, whose boundaries are marked by distinctive patterns in the archaeological record" (Stark 1998:1). Although material 
culture often plays an active role in social interaction, especially in the expression of social status and identity, it is not easy to articulate a straightforward relationship between artifact and identity (Janusek 2002:37). It has been argued that, rather than relying on a single category of material culture, the researcher must employ a careful, multivariate approach to interpret the identity and the links between material data and past social processes (e.g., Dietler and Herbich 1998; Janusek 2002). Emberling suggests a series of steps in the process of identifying markers of identity (Emberling 1997:311). First, one must identify a potentially distinctive group. Then, the social and geographical boundaries of the alleged group must be established by comparing patterns of artifact classes with those of neighboring groups. Through the careful study of production and use, it might then be possible to characterize the kind of group associated with those artifact classes. Finally, these patterns should be compared with other categories of evidence to substantiate claims of ethnic difference.

Even this cursory overview of the sites and material culture from Kerala and Tamil Nadu highlights a key point: despite the common tendency for South Indian historians and archaeologists to speak of "Tamil" material culture, the archaeological evidence that sets Tamilakam as a region apart from the rest of South India has never been clearly identified. If one evaluates Tamil cultural identity using Emberling's guidelines, then the claims of ethnic difference appear to falter, since nearly all the material culture found in Tamilakam-that is, in Kerala and Tamil Nadu_can be found elsewhere in peninsular India. Similarly configured urban centers and habitation sites are located throughout South India and Sri Lanka. And, although the majority of Iron Age burials are situated in South India, they are widely distributed throughout the Indian subcontinent, and only one or two types are unique to Tamilakam. In the same way, the distribution of ceramics, iron, and other artifacts are dispersed across the alleged past cultural-ethnic, linguistic, and geographic boundaries of South India.

Indeed, what seems to distinguish Tamilakam material cultural formations during the late Iron Age-Early Historic period is the lack of some kind of evidence one finds in neighboring regions; the Deccan region immediately to the north, for example, is notable for its large number of both simple and elaborate Buddhist sites, as well as for the wide array of numismatic finds-examples of locally minted coins that have helped to reconstruct the political dynasties of the early Deccan. Archaeological, inscriptional, and numismatic data indicate that the Deccan followed a different historical trajectory - it was part of the Mauryan realm until its decline in the third century B.C., after which a cluster of later rulers claimed the territory, the most important being the Satavahanas. So, too, is there a separate story for Sri Lanka, whose Early Historic period is said to have begun with northern Indian merchants settling on the island, followed by the introduction of Buddhism by an envoy of the Mauryan king Aśoka in the third century B.C. (Bopearachchi 1997 : xvi).

\section{“MATERIALIZING" THE TAMIL IDENTITY}

Given the nature and distribution of sites and artifacts across the Tamil landscape, it has been difficult to discern a pattern of style or symbol or process that stands out, making simplistic normative notions of a Tamil identity appear misplaced. 
In fact, except for the linguistic evidence, it would be challenging to identify a "Tamil" artifact or site on the basis of the physical or stylistic traits alone. Perhaps the only identifiably "Tamil" artifacts are the cave and pottery inscriptions, but they have not been studied for the express purpose of establishing evidence about the identity of Tamilakam. It seems plausible to suggest that our scholarly consciousness of a Tamil land and the subsequent attribution of "Tamilness" to material culture are based on the poorly articulated relationship between texts and artifacts in early South India. The tendency of historians and archaeologists to assign a text-based "Tamil identity" to objects and sites found in the Tamil region may have obscured the possibility that more than one dialogue was in progress. In the case of Tamilakam, a central concern must be how people used their material culture to define themselves and to express their affiliations. In his study of later prehistoric Europe, Wells (1998) mentions three basic ideas that have opened up the archaeological study of identity: first is the view that material culture serves as an active agent for constructing meanings and communicating information with others; second, identity is not a static attribute, but instead a dynamic, flexible, and contingent property; third is the application of individual agency to the study of archaeological contexts (Wells 1998:240-241).

Furthermore, textual sources must not be taken at face value, but rather, "considered in terms of the social and political contexts in which they were produced, and positions and interests of the authors and the audiences, and the active role which texts may have played in the construction and negotiation of cultural identity" (Jones 1999:223-224). It is perhaps not a coincidence, in this formative stage of Tamil social history, that both the Sangam texts and external references to Tamilakam concentrate on military and political endeavor. As mentioned, the Sangam poems are essentially heroic court poetry in praise of the military prowess of various Tamil rulers as they competed for territory and the spoils of plunder. The external inscriptions are by polities that are supposed to have attempted, or profited by, hostile incursions into the region. In addition to the rock edicts of the Mauryan ruler Aśoka, there is a reference in a Sangam poem to a Mauryan invasion of the south. The Hathigumpha inscription describes a league of Tamil states strong enough to constitute a threat to the safety of the northern Kalinga polity and claims that a Tamil league or confederacy had been in existence 113 years before (Kant 2000:39). If group distinctiveness functioned as a strategy to develop, maintain, and justify elite activities, then the early Tamil texts may signal the efforts of petty rulers to promote a nascent self-awareness based on linguistic and historical commonalities. This would be consistent in a context where the development and maintenance of a supposed regionwide identity was necessary in order to muster support and resources in the face of internal and external threats. With this approach, such expressions of identity lead, not to an archaeological reification of such groups, but instead to an appreciation that identity may vary depending on social domain and with relation to different scales of social interaction (Jones $1997: 129$ ).

The material culture of early Tamil South India, on the other hand, does not obviously expose to us markers of a regional Tamil ethnicity or identity, and one partial explanation may be that it reflects not the self-consciousness regionalism of the documents, but a pattern of social and cultural processes that were primarily small-scale, self-organized, or at least not controlled to a great degree by the soi- 
disant rulers of Tamilakam. In this case, the archaeological data represent complementary (and perhaps competing) perspectives of identity compared to those of the South Indian texts. The activities and concerns represented by Tamil artifacts are less apparently political than they are economic and social-aspects of lifestyle in which an ethnic symbolism was not recorded in the conspicuous manner found in the texts. From this perspective, it may not be a surprise to find archaeologists agreeing that the activities best illustrated in the Tamil material record have to do with trade, hunting, agriculture, and craft industries, and it may be in such activities that identity is situated. Tamil identity may be sought in those assemblages that direct attention to regional distinctions in trade strategies, for example, such as the patterns in Roman artifact distribution in Tamilakam that contrast strikingly with the neighboring Deccan region. Although both regions participated in long-distance Indian Ocean trade during the Early Historical period, the Deccan contains a large number of Roman artifacts, while the bulk of Roman material in Tamilakam is in the form of Roman silver and gold coin hoards. Romila Thapar (1992) has suggested that this variability indicates unique patterns of trade organization; if so, material signatures of identity may reside not in static interpretations of the archaeological data, but in understanding the distinct socio-economic processes in which each region was engaged.

If the extent to which the larger populace embraced a common Tamil identity is debatable, the answer may lie in a re-evaluation of the scale of analysis (Feinman 1997:375). If daily Tamil life as represented by material culture was most likely local rather than regional, chances are that the material assemblages here reveal systems of identity that did not extend beyond the village, settlement, or community level. As rich as the Sangam textual corpus is, for example, the bulk of the information contained within it focuses narrowly on the activities of the elite rulers and warriors, much like the texts originating in many early states and civilizations (Adams 2001:347). Such a focus overshadows the data on the daily lifestyles and activities of the majority of the populace. In the search for alternative models, however, a re-examination of the Sangam texts reveals clues regarding a system of local identities that might have greater relevance for the South Indian archaeologist. In contrast to the better-known themes of kingship, warfare, and plunder, the aintinai theme of the Sangam anthologies concerns the division of Tamilakam into a series of microecological zones-a fivefold physiographic division of the landscape - that comprised coastal regions, hilly backwoods, pastoral tracts, riverine wetlands, and arid-parched zones (Champakalakshmi 1996:96). Associated with these microzones were different forms of production and social formation, ranging from hunting-gathering to animal husbandry, shifting agriculture, wetland agriculture, fishing, and salt manufacture. To date, almost no consideration has been given by South Indian archaeologists to this representation of ancient Tamil life, yet it is an opportunity to appreciate the multiple and multiscalar dialogues present in the Sangam texts and address their implications for interpreting identity in the South Indian material record. Perhaps ethnic identity was not a salient social feature, as has been assumed for protohistoric Kerala and Tamil Nadu. Instead of accepting received notions of a region-based "Tamilness," it may be more useful to the archaeologist to consider smaller, resource-based distinctions as the more appropriate scale of analysis when examining the archaeological record of Kerala and Tamil Nadu. 


\section{CONCLUSION}

By uncritically subsuming the study of artifacts under the study of texts, Tamil scholars are in danger of missing important social strategies and practices contained in both the textual and material data, and impoverishing our understanding about the complexities of the Tamil past. The discussion presented here suggests one method by which the documentary and material records for Kerala and Tamil Nadu may be integrated, while at the same time guarding against some of the broad tendencies described by Feinman (1997): the preference for documents at the expense of archaeological data; the unsystematic and selective use of textual records by archaeologists; and the lack of attention paid to spatial and chronological scales of analysis. Consciously and critically addressing these issues may allow South Indian scholars to determine what, if anything, distinguishes, "the cool land of the Tamils" from the rest of peninsular South India.

\section{REFERENCES CITED}

AdAms, R. MCC.

2001 Complexity in archaic states. Journal of Anthropological Archaeology 20:345-360.

BEGLEY, V.

1992 Ceramic evidence for pre-Periplus trade on the Indian coasts, In Rome and India: The Ancient Sea Trade: 157-196, ed. V. Begley and R. D. de Puma. Madison: University of Wisconsin Press.

1996 Ancient Port of Arikamedu: New Excavations and Researches 1989-1992, vol. 1. Pondichery: Ecôle Française d'Extrême Orient.

BopearachCHI, O.

1997 Foreword, in Tabropane: Ancient Sri Lanka as Known to Greeks and Romans: ix-xxii, ed. D.P.M. Weerakoddy. Turnhout: Brepols.

BrubAKER, R.

2001 Aspects of mortuary variability in the South Indian Iron Age. Bulletin of the Deccan College Postgraduate and Research Institute: 60-61 (2000-2001) : 253-302.

Champakalakshmi, $\mathrm{R}$.

1996 Trade, Ideology and Urbanization: South India 300 B.C. to A.D. 1300. Delhi: Oxford University Press.

Charlesworth, M. P.

1926 Trade-Routes and Commerce of the Roman Empire. Chicago: Ares Publishers, Inc.

Dietler, M., AND I. Herbich

1998 Habitus, techniques, and style: An integrated approach to the social understanding of material culture and boundaries, in The Archacological of Social Boundaries: 232-263, ed. M. Stark. Washington, D.C., and London: Smithsonian Institution Press.

Emberling, G.

1997 Ethnicity in complex societies: Archaeological perspectives. Journal of Archaeological Research 5(4) : 295-344.

Feinman, G. M.

1997 Thoughts on new approaches to combining the archaeological and historical records. Journal of Archaeological Method and Theory 4(3-4):367-377.

Gogte, V. D.

1997 The Chandraketugahr-Tamluk region of Bengal: Source of the Early Historic Rouletted Ware from India and Southeast Asia. Man and Environment 22(1) :69-85.

GurukKal, R.

1989 Forms of production and forces of change in ancient Tamil society. Studies in History $5(2): 159-175$.

1995 Beginnings of the Historic Period: The Tamil south, in Recent Perspectives of Early South Indian History: 237-265, ed. R. Thapar. Bombay: Popular Prakashan. 
Gurukkal, R., and M.R.R. Varrier

1999 Cultural History of Kerala, vol. 1. Thiruvananthapuram, Kerala: Department of Cultural Publications, Government of Kerala.

Gurumurthy, S.

1991 Ceramic Traditions in South India, down to 300 A.D. Madras: University of Madras.

Hart, G. L.

1975 The Poems of Ancient Tanil: Their Milien and Their Sanskrit Connterparts. Berkeley: University of California Press.

Hart, G. L., and H. Heifetz, trans. and eds.

1999 The Four Hundred Songs of War and Wisdom: An Anthology of Poems from Classical TamilThe Ptiranainitii. New York: Columbia University Press.

HEGMON, M.

1998 Technology, style, and social practices: Archaeological practices, in The Archaeology of Social Boundaries: 264-270, ed. M. Stark. Washington and London: Smithsonian Institution Press.

JANUSEK, J. W.

2002 Out of many, one: Style and social boundaries in Tiwanaku. Latin American Antiquity $13(1): 35-61$.

JONES, S.

1997 The Archaeology of Ethnicity. London and New York: Routledge.

1999 Historical categories and the praxis of identity: The interpretation of ethnicity in historical archaeology, in Historical Archacology: Back from the Edge: 219-232, ed. P.P.A. Funari, M. Hall, and S. Jones. London and New York: Routledge.

KANT, S

2000 Hathigumpha Inscription of Kharavela and the Bhabru Edict of Asoka: A Critical Study. Delhi: D. K. Printworld.

KENNEDY, R. S.

1976 The king in early South India, as chieftain and emperor. Indian Historical Revicw $3(1): 1-15$.

Kosso, P.

1995 Epistemic independence between textual and material evidence, in Methods in the Mediterranean: Historical and Archaeological Views on Texts and Archaeology: 177-196, ed. D. B. Small. Leiden: E. J. Brill.

Kulke, H., AND D. Rothermund

1986 A History of India. Calcutta: Rupa and Co.

Leone, M. P., And C. Crosby

1987 Middle-range theory in historical archaeology, in Consumer Choice in Historical Archaeology: 397-410, ed. S. Spencer-Wood. New York: Plenum Press.

LeOne, M. P., And P. B. Potter

1988 Introduction: Issues in historical archaeology, in The Recovery of Meaning in Historical Archacology in the Eastern United States: 1-22, ed. M. P. Leone and P. B. Potter. Washington, D.C.: Smithsonian Institution Press.

LESHNIK, L. S.

1974 South Indian 'Megalithic' Burials: The Pandukal Complex. Wiesbaden: F. Steiner.

MahadeVAn, I.

1993 Ancient Tamil contacts abroad: Recent epigraphical evidence. Journal of the Institute of South Asian Studies 12(1): 136-155.

Mahalingam, T. V.

1970 Report on the Excavations in the Lower Kaveri Valley (Tirukkampuliyur and Alagarai). Madras: University of Madras.

MCCrindle, J. W.

1971 [1901] Ancient India as Described in Classical Literature. New Dehli: Munshiram Manoharlal.

MCIntosh, J.

1985 Dating the South Indian megaliths, in South Asian Archacology 1983: 467-493, ed. J. Schotsmans and M. Taddei. Naples: Istituto Universitario Orientale Dipartimento Di Studi Asiatici. 
MoOrti, U. S.

1994 Megalithic Culture of South India: Socio-Economic Perspectives. Varanasi: Ganga Kaveri Publishing House.

Morrison, K. D., AND M. Lycett

1994 Centralized power, centralized authority? Ideological claims and archaeological patterns. Asian Perspectives 32:312-353.

1997 Inscriptions as artifacts: Precolonial South India and the analysis of texts. Journal of Archaeological Method and Theory 4(3-4):215-237.

Munro-Hay, S.C.H.

1996 Aksumite interests overseas, in Indian Ocean in Antiquity: 403-416, ed. J. Reade. London and New York: Kegan Paul International and The British Museum.

Nagaswamy, R.

1995 Roman Karur. Madras: Brahad Prakashan.

RAJAN, K.

1994 Archaeology of Tamil Nadu (Kongu Country). Delhi: Book Indian Publishing Co.

RamaCHANDRAN, K. S.

1980 Archaeology of South India: Tamil Nadu. Delhi: Sundeep.

RAMAN, K. V.

1988 Excavations at Uraiyur (Tiruchirapalli), 1965-69. Madras: University of Madras.

RAY, H. P.

1989 Early historical settlement in the Deccan: An ecological perspective. Man and Environment 14(1): 103-108.

1994 The Winds of Change: Buddhism and the Maritime Links of Early South India. Delhi: Oxford University Press.

1995 Trade and contacts, in Recent Perspectives on Early Indian History: 142-167, ed. R. Thapar. Bombay: Popular Prakashan.

Saloman, R.

1991 Epigraphic remains of Indian traders in Egypt. Journal of the American Oriental Society 111(4): 731-736.

SASTRI, N.

1966 A History of South India. Madras: Oxford University Press.

Shanks, M., AND C. TIlley

1987 Reconstructing Archaeology: Theory and Practice. Cambridge: Cambridge University Press.

SHENNAN, S.

1989 Introduction: Archaeological approaches to cultural identity, in Archaeological Approaches to Cultural Identity: 1-32, ed. S. J. Shennan. London and New York: Routledge.

Sidebotham, S. E.

1986 Roman Economic Policy in the Erythra Thalassa, 30 B.C.-A.D. 217. Leiden: E. J. Brill.

SOUndara Rajan, K. V.

1994 Kaveripattinam Excavations 1963-73 (A Port City on the Tamilnadu Coast). New Delhi: Archaeological Survey of India.

SмIтн, M. L.

1999 'Indianization' from the Indian point of view: Trade and cultural contacts with Southeast Asia in the early first millennium CE. Journal of the Economic and Social History of the Orient $42(1): 1-26$.

STARK, M.

1998 Technical choices and social boundaries in material culture patterning: An introduction, in The Archaeology of Social Boundarics: 1-11, ed. M. Stark. Washington, D.C., and London: Smithsonian Institution Press.

THAPAR, R.

1992 Black gold: South Asia and the Roman maritime trade. South Asia 15(2):1-27.

Thurston, T.

1997 Historians, prehistorians, and the tyranny of the historical record: Danish state formation through documents and archaeological data. Journal of Archaeological Method and Theory $4(3-4): 239-263$. 
WELLS, P. S.

1998 Identity and material culture in the later prehistory of Central Europe. Journal of Archaeological Research 6(3):239-298.

Whitehouse, D., and A. Williamson

1973 Sasanian maritime trade. IRAN 11.

WYLIE, A.

1985 The reaction against analogy. Advances in Archacological Method and Theory 8:63-111.

ZVELEBIL, K.

1992 Companion Studies to the History of Tamil Literature. Leiden: E. J. Brill.

\section{ABSTRACT}

For the southern Indian states of Kerala and Tamil Nadu, the most important documentary source for information on early South Indian culture is a body of prose poetry known as the Sangam anthology. These indigenous texts date to the first few centuries A.D. and comprise the earliest extant examples of Tamil literature. Not surprisingly, this is also the period to which can be traced the first indications of the concept of a "Tamil" identity in South India. Archaeologically, the Tamil Sangam era corresponds roughly to the late Iron Age-Early Historic period (c. 300 B.C. to A.D. 300), which represents a key stage in the development of South Indian material culture. Prevailing analyses of early Tamil society have relied heavily on the historical texts, often at the expense of critically examining the material culture from Kerala and Tamil Nadu. This study examines the relationship between South Indian archaeology and history and argues that any framework for interpreting early Tamil identity must acknowledge the important qualitative differences in the ways that texts and artifacts construct and reflect ethnic identity, and that archaeologists and historians must analyze their respective data sets within the larger social, political, and economic practices of early Tamilakam. Keywords: South Asia, South India, Tamilakam, Kerala, Tamil Nadu, history and archaeology, cultural-ethnic identity. 